\title{
Alix Green \\ Professional Identity and the Public Purposes of History
}

\section{Commentary}

Professional identity is a central concern of these three papers; my commentary takes this notion as a lens through which to view the nexus of historical knowledge and practice, history education, politics and citizenship. To do so is, quite deliberately, to encourage a reflexive turn - to recognise that who we think we are as historians, archivists or history educators is as relevant as how we characterise our constituencies: students, legislators, publics and so on. This endeavour is partly about where we understand the parameters of our crafts to lie, and how these communities of practice relate to and engage with one another. There is certainly a central and common concern with the past as it is presented and represented in the present and to a variety of audiences. Professional identity also, however, prompts more searching questions about authority (and its limits). They - we - are not merely concerned with the past. We also claim a kind of 'mandate' over it, whether we see ourselves as gatekeepers, custodians, guides or perhaps experts of another kind. In doing so, we must seek to understand how such a claim conditions the relationships we have with those constituencies.

Let us explore, and complicate, this theme of authority further. These mandates are often taken to rest on credentials. Public historians - if we can appropriate the 'umbrella term' 1 - are like other professional communities in taking our authority from training and qualifications, from experience and status, and from the job roles that we occupy. Such mandates are never stable, nor are they uncontested - particularly now. The internet has enabled wider access to information and new, diverse and dispersed communities of knowledge have emerged. ${ }^{2}$ History is perhaps distinctive in that this challenge to professional status is far from new; a longer, and intellectually important, lineage lies in the idea of history as "the work... of a thousand hands", as Raphael Samuel so vividly described it. ${ }^{3}$

1 Ludmilla Jordanova, History in Practice, 2nd ed. (London: Hodder Arnold, 2006).

2 Richard Susskind and Daniel Susskind, The Future of the Professions: How Technology Will Transform the Work of Human Experts (Oxford: Oxford University Press, 2015).

3 Raphael Samuel, Theatres of Memory: Past and Present in Contemporary Culture (London: Verso, 2012), 18.

2 Open Access. (C) 2018 Alix Green, published by De Gruyter. (c) BY-NC-ND This work is licensed under the Creative Commons Attribution-NonCommercial-NoDerivatives 4.0 License. https://doi.org/10.1515/9783110466133-012 
Less readily acknowledged is that elected politicians also claim a stake in the content and status of historical knowledge through the provision and regulation of state-funded education. Of all the subjects taught in schools, history has been most often on the political front line, as 'textbook wars' in Australia, the United States and Japan, among many others, have shown (it is worth noting, however, that the very centrality of historical narrative to the politics of identity has also made the textbook a tool of reconciliation, as in the case of the Polish-German joint textbook commission). ${ }^{4}$ Whether they are acting as ministers in government, as members of legislative or scrutiny committees or just as elected representatives, politicians draw their mandates for involvement in school history from the democratic system - and thus, ultimately, from the concerns and interests of wider society: the public. In defending these mandates, politicians often invoke a pervasive sense that social cohesion relies on shared identity and values, and those in turn on knowledge of - usually national - history.

Of course, the 'public' also have their own claims on history. The public is - we are - no homogenous mass, but made up of blurred and shifting groups and networks. Multiple pasts shape multiple identities, beliefs and attitudes, sometimes complementary, sometimes overlapping or conflicting. Education is one of the policy areas in which these difficult and contentious pasts are most prominent, but we can also see their influence at the moment in debates about immigration and borders, the future of Europe in all its complexities, intervention in Syria and many others.

For historians, these other mandates are often highly problematic, and the emerging field of public history has by no means resolved anxieties about what happens to history outside professional control. Drawing on Samuel's legacy, ideas of shared authority have been celebrated in the British discipline of history, if not widely or consistently practised. ${ }^{5}$ There has been a marked disinclination, however, to extend such work from local and community history or museum contexts into the policymaking domain. These inconsistencies should suggest to us the need to look again at our own attitudes, assumptions and commitments. The mandates of politicians and the public over the past may have a different derivation from those claimed by historians, but can we question their legitimacy on that basis? Perhaps it is not so much the mandates themselves, however troublesome we may find them, but rather the entitlements taken to flow from a

4 See: accessed September 1, 2016, www.gei.de/en/departments/europe-narratives-images-spaces/ europe -and-the-national-factor/german-polish-textbook-commission.html.

5 See for example: Laura King and Gary Rivett, "Engaging People in Making History: Impact, Public Engagement and the World Beyond the Campus," History Workshop Journal (June 16, 2015). 
particular mandate and the challenges in managing the tensions and incompatibilies that inevitably arise between mandates.

In raising the issue of entitlements, we can, again, start in reflexive mode. How self-conscious are we about the status and privileges attached to our own professional roles? Here, I wonder if historical scholarship is somewhat ahead of the habits and dispositions of historians themselves. Historians now widely recognise that our understanding of the past is present-oriented, provisional, unstable and negotiated, yet we are often less comfortable with the implications of this understanding. That is, can we assume that our entitlement to guard or mediate access to the past is secure if we are not talking of singular, 'authorised' accounts but plural, contested interpretations that are constantly being made and remade (and not just by us)?

E. H. Carr memorably described history as "a continuous process of interaction between the historian and his [sic] facts, an unending dialogue between the present and the past". ${ }^{6}$ To those conversations must be added exchanges within and between professional communities, and also with audiences, consumers, recipients and associates of various kinds. All this means, I suggest, that we cannot simply 'take' our authority or assume our entitlements. Rather, we must realise, as geographer Sally Eden has argued, that expertise is 'built contingently' and has to be continually re-negotiated with those on whose recognition our expert status depends. ${ }^{7}$ Who those people are is worth some thought - colleagues, peers, students, funders, readers? - as is how we see those constituencies and their claims on our attention. Introducing contingency means acknowledging that patterns of recognition and responsibility shift over time, often with changes in our professional roles and interests. So perhaps our authority and influence as historians are better understood not as substantive entities or inherent qualities, nor indeed as possessions (such as credentials) - but as "attribute[s] of the relationships within which [they are] exercised". ${ }^{8}$

To think in relational terms about our expertise is, I admit, challenging. We must critically examine our sense of the professional self. And, in the case of school history education, the relationships in question are highly problematic, particularly - as the papers in this section demonstrate - those with policymakers. In Britain, the construction of an 'educational establishment' in political discourse has made any conversation about the connection between historical

6 Edward Carr, What Is History? (Basingstoke: Palgrave Macmillan, 2002), 24.

7 Sally Eden, "Green, Gold and Grey Geography: Legitimating Academic and Policy Expertise," Transactions of the Institute of British Geographers 30, no. 3 (2005).

8 Christopher Clark, "Power," in A Concise Companion to History, ed. Ulinka Rublack (Oxford: Oxford University Press, 2011). 
knowledge, historical understanding and history education hugely challenging. More provocatively, this leftist agglomeration of teachers' unions, academics, civil servants and others has been labelled 'the blob'. The term was imported from the United States by former Education Secretary Michael Gove. It conveniently lumps together a diverse range of professions to create a faceless, formless 'other' that can be easily dismissed as inveterately hostile to government scrutiny and reform, often pursued under the flag of raising standards (the anti-expert rhetoric of the recent Brexit referendum campaign drew its energy from the same source). With regards to history education, there is a further indictment to be added to the blob's record. As Margaret Thatcher put it: "a whole generation has been brought up to misunderstand and denigrate our national history... for the blackest picture is drawn by our Socialist academics and writers of precisely those periods of our history when greatest progress was achieved compared with earlier times, and when Britain was furthest in advance of other nations". 9

This charge points us to the key site of conflict between two mandates over the past: that of historians (broadly understood here as teachers, historians and scholars of pedagogy) and that of government. In the selection of topics and events children should be taught, notions of historical significance become inflected with judgements about political and social significance - the extent to which those topics or events were constitutive of national narratives, for example, about principles of democracy or free speech, values such as tolerance or about advances in industry and science. These two understandings of significance do not sit compliantly alongside each other, and tension between politicians and historians is inevitable, if not inevitably incendiary.

Teaching the passing of the Abolition of the Slave Trade Act in 1807 does not preclude exposing students to longer views of Black settlement in Britain or to histories of Black achievement and resistance. Nor should it elide British participation in and profit from the trade in enslaved people, the financial legacies of which have been traced into the present by an important project at University College, London. ${ }^{10}$ Yet the term 'legacy' points us towards why what children learn about the past is, nonetheless, such a fraught issue. The social and political legacies of the slave trade are multiple, complex and elusive. They can intrude in often insidious, sometimes brutal, ways on people's lives and on wider public consciousness, from everyday discrimination to racially-aggravated violence.

9 Hugh Thomas, History, Capitalism and Freedom (London: Centre for Policy Studies, 1979), Thatcher wrote the Foreword.

10 See https://www.ucl.ac.uk/lbs/ 
Recognising - and teaching children about - historical injustice becomes easily caught up with the present-day politics of identity, condemned in Britain as corrosive 'post-colonial guilt' that obscures narratives of pride and progress. ${ }^{11}$ We can see in Gautschi's paper a similar pattern, with the Swiss People's Party rejecting as ideological 'indoctrination' a textbook encouraging students to engage actively and critically with the Nazi period. Gove's proposals aimed to challenge a supposedly anti-British agenda in the current history curriculum. That he was later prominent in the campaign to leave the EU should come as no surprise; we can connect attitudes to Britain's imperial past to beliefs about her (extra-)European future.12 Indeed, the conspicuous neglect of Europe identified by Richard Evans in Gove's 2013 proposals for revising the history National Curriculum acquires fresh significance, if not a darker cast, following the referendum result. ${ }^{13}$

By attributing great political importance to the selection of topics for children to study, a false dichotomy is created between content coverage and the development of skills. There is so much weight attached to 'knowing' (an authorised past) that attempts to create space for students to develop those vital disciplinary techniques of appraisal, analysis and interpretation read not just as misguided but as suspect. Indeed, the development of a National Curriculum for England and Wales emerged from a moral panic among the political Right about the impact of 'progressive' or 'fashionable' practices on standards in schools. ${ }^{14}$ History was a subject that drew particular attention, with the Schools Council History Project (SCHP) encapsulating the approbium. It had been set up by the Schools Council in 1972 to revitalise a subject with which pupils struggled to engage. ${ }^{15}$ By the end of the 1980s over a third of schools were teaching the syllabus, which encouraged pupils to consider the perspectives of people to whom historical attention had rarely been given. SCHP placed the development of historical skills and

11 Lévesque has called these master narratives 'memory-history', which we can distinguish from disciplinary-history: Stephane Levesque, Thinking Historically: Educating Students for the Twenty-First Century (Toronto: University of Toronto Press, 2008), 27.

12 Sally Tomlinson and Danny Dorling, "Brexit Has Its Roots in the British Empire - So How Do We Explain It to the Young?,” New Statesman, May 9, 2016.

13 Richard J. Evans, “Michael Gove’s History Wars,” Guardian, July 13, 2013.

14 On the 'moral panic' on school standards: Keith Crawford, "A History of the Right: The Battle for Control of National Curriculum History 1989-1994," British Journal of Educational Studies 43, no. 4 (1995): p. 434.

15 On SCHP, see: Rosalyn Ashby and Christopher Edwards, "Challenges Facing the Disciplinary Tradition: Reflections on the History Curriculum in England," in Contemporary Public Debates over History Education, eds. Eire ne Nakou and Isabel Barca (Greenwich, Conn.: Information Age, 2010). 
understanding in the foreground and emphasised the plural interpretations of historical evidence. ${ }^{16}$ Affinities with the competence-based approach developed contemporaneously in Austria are clear.

It should be noted that this dichotomy of knowledge versus skills was not solely the preserve of politicians. An understandable response to a 'whitewashed' curriculum is to propose a more balanced, representative alternative. These challenges are important, but exchanging lists of who or what should be 'in' or 'out' only goes so far. An underlying problem is that professional history in its various forms also tends to prize the accumulation and display of knowledge. We confer an almost sacred status on the artifacts collected in archives, libraries and museums and accord professional esteem for the end products of research books, articles, exhibitions and so on. But the complex, careful, skilled labour involved in between is largely hidden from view. ${ }^{17}$ How we articulate and explain what it is historians do, why and for whom seem to me important questions. They are made urgent by a political context in which the whole notion that expertise can usefully inform policy and public debate is subject to dispute and the humanities, in particular, are being pressed to prove their worth.

Historians have not, of course, been absent from political debate, from school history to welfare reform to Brexit. ${ }^{18}$ The problem, however, is that we are often in reactive mode - and the provocations are flagrant and frequent enough that response becomes a proxy for engagement. We defy and we rebut. Even while recognising the blob as a demon conjured up by the political right, we find the characterisation impossible to ignore. But the provocation is a trap as well as a rhetorical device, as Gove demonstrated well when he mocked scholars and educators as "bad academia" for criticising his plans for "children to learn things". ${ }^{19}$ As soon as we react, individually or collectively, we reveal ourselves as blobberati, as experts or elites, whichever term is currently being used to aggregate and marginalise professional communities. A troubling tactic - setting expertise quite deliberately at odds with 'public good' and 'public opinion' - was seen in the Brexit referendum campaign. ${ }^{20}$

16 See: Crawford, pp. 435-6; Abby Waldman, "The Politics of History Teaching in England and France During the 1980s,” History Workshop Journal 68, no. 1 (2009): pp. 202-3; Ian Dawson, “The Schools History Project: A Study in Curriculum Development," The History Teacher 22, no. 3 (1989).

17 Jordanova, History, 161-163.

18 See in particular the work of the History and Policy network: www.historyandpolicy.org.

19 Jessica Shepherd, "Michael Gove Labels Professors Critical of New Curriculum as "Bad Academia”," The Guardian, March 21, 2013.

20 See for example: Ben Wright, “There's a Sinister Strain of Anti-Intellectualism to Gove's Dismissal of 'Experts'," Telegraph, June 21, 2016. 
While it is vital that historians hold politicians, the media and others to account for false or tendentious uses of the past, reactive mode will only get us so far if we want to be able to define and explain our professional roles in ways that elicit trust and recognition. This means, I suggest, seeing past the provocation and trying to identify the broader questions and values at stake when caricatures such as the blob can find such a ready traction. Have our efforts to talk about learning history, about the value of historical reasoning and understanding and the importance of investing in the resources that give people access to the past been compelling to wider audiences? I wonder if our inclination to emphasise specialist identities (teacher, academic historian, archivist, curator and so on) has tended to undermine our professional credibility and influence. Could we create a more fluid and inclusive 'community of enquiry' that helps us all intellectually and in our relationships with political power - and the public?

One of the problems we could, perhaps, tackle together is the paradox of history being at the same time of central importance (that is, as a way of building civic identity through education) and of marginal value (so, of little economic utility in the so-called 'knowledge economy'). Let us unpack this paradox a little further. On the one hand, history clearly matters. It can sadden, offend, enliven and engage. It can define and it can dismantle ideas, identities and boundaries. It promises the ultimate appeal to justify one course of action or to render another indefensible. It can be seen to burden or to bolster a political party or a leader. Two powerful, historically-conditioned models of Britishness clashed in the referendum campaign: is Britain distinctive and apart in its institutions and traditions or fundamentally interconnected with continental Europe?21

So, to return to education, one important way history matters is that it gives us a more richly informed understanding of the present - not by means of crude 'lessons', but by developing the ability to ask searching questions (about immigration, human rights or welfare, for example). As people seek answers, reflect and return with further questions, they gain insights into the broader historical contexts and longer-term import of the policies under debate. Indeed, when the English and Welsh National Curriculum for history was first developed, one of the purposes identified for learning history was to "prepare pupils for adult life... [by giving them] a critically sharpened intelligence with which to make sense of current affairs". ${ }^{22}$ But there was an evident 'dissonance' between the aims of the

21 These two positions were taken up by opposing historians' collectives, Historians for Britain, accessed September 26, 2016, www.historiansforbritain.org, then in response, Historians for History, accessed September 26, 2016, www.historiansforhistory.wordpress.com.

22 Department of Education and Science, "National Curriculum History Working Group: Final Report," (London: H.M.S.O., 1990), 1-2. 
curriculum and the 'arrangements and systems for delivering them', the latter bearing the imprint of content coverage and the 'canon' of British - essentially English - history. ${ }^{23}$

We return here to political emphasis on knowing over active critical engagement. Indeed, when Kenneth Clarke became Education minister in John Major's first government (after Margaret Thatcher's resignation in 1990), he ordered political history to stop twenty years before the present, as if to insulate the now and young people - from the toxicity of historical attention. This stricture was removed in 1995, but it does suggest ambivalence about the prospect of students emerging duly equipped with 'critically sharpened intelligence'. The saying goes that 'a little knowledge is a dangerous thing', but perhaps, following Hellmuth's paper, it should instead read 'a little Mündigkeit...'. The English translation of Mündigkeit, 'responsibility', does not adequately capture the sense of agency and self-efficacy of the German word. My sense is that many historians, and scholars of historical pedagogy, would embrace the notion that history develops Mündigkeit. The discipline has prided itself on its 'disruptive' or 'destructive' credentials, the appeal of which must partly lie in the capacity to unsettle complacencies, dismantle received wisdoms and hold authority to account. ${ }^{24}$

Yet beyond notions of fostering shared identity, history, and the humanities more broadly, have tended to be cast by policymakers not as dangerous but as pointless - a far more troubling verdict from the perspective of historians. The discipline has struggled to articulate in ways persuasive to policy the value of history as a form of knowledge. "What counts is what works" was a manifesto slogan of New Labour on its way to ending eighteen years of Conservative government in Britain: the pitch of a modern, unideological party fit for power. Later formalised through electoral success into the doctrine of 'evidence-based policymaking' (EBPM), the phrase neatly captures a policy climate unconducive to expressions of uncertainty and complexity that are central to the humanities. ${ }^{25}$ EBPM is highly problematic in both conception and implementation, invoking a simplistic rationalism that relies on misunderstanding scientific as well as humanistic

23 Terry Haydn, “History,” in Rethinking the School Curriculum: Values, Aims and Purposes, ed. John Nov White (London: RoutledgeFalmer, 2004), 91-92.

24 Russell H. Hvolbeck and Peter N. Stearns, "Thinking and Rethinking History," in History Anew: Innovations in the Teaching of History Today, ed. Robert Blackey (Long Beach, Calif.: California State University Press, 1993); John Cannon, “Teaching History at University,” The History Teacher 22, no. 3 (1989).

25 Peter Wells, “New Labour and Evidence Based Policy Making: 1997-2007,” People, Place \& Policy Online 1, no. 1 (May 22, 2007); Wayne Parsons, "From Muddling through to Muddling up Evidence Based Policy Making and the Modernisation of British Government,” Public Policy and Administration 17, no. 3 (2002). 
methods. ${ }^{26}$ It is a model into which the discipline of history is not readily accommodated, perhaps best illustrated in comments made by Charles Clarke in 2003, then Education and Skills Secretary in Tony Blair's second administration. When he needed an example of a subject without uses, it was to medieval history he turned: "I don't mind there being some medievalists around for ornamental purposes, but there is no reason for the state to pay for them". ${ }^{27}$

Perhaps Canadians should therefore be cautious in welcoming the former head of Blair's Delivery Unit, Michael Barber, as a close consultant to Justin Trudeau's Liberal administration. ${ }^{28}$ On first inspection, Barber's doctrine of 'deliverology' captures the obvious of good government - you gather and analyse data then use it to monitor progress and so keep political promises - but like many self-evident truths it is far from neutral. Encoded in it is a set of values and assumptions that need to be exposed and inspected: here, about the nature of policymaking and the role of the executive, the mechanisms and levers available for policy implementation and the relationship between government and governed (among many others). What does not fit in the world of deliverology is the irreducible, unpredictable 'messiness' of being human and living in society. The humane disciplines have celebrated and taken as their especial concern the tensions, ambiguities and instabilities of human identity, judgement and expression - but rather than being recognised as providing insights vital for politics in a messy world, humanities scholars have been marginalised from policy. Indeed, the conceptualisation of the humanities as 'elective', the sciences by contrast as 'essential', has become widely assimilated into political discourse. ${ }^{29}$ An extreme example is the letter sent by Japan's Minister of Education in 2015 instructing all universities to 'abolish' their social science and humanities programmes, or "to convert them to serve areas that better meet society's needs". ${ }^{30}$

I have suggested that creating a more inclusive community of enquiry might be one way to reframe our relationship as historians with political power. To pursue that idea, should we also be asking how far inclusivity might go? Responding to

26 I discuss this in: Alix Green, "History as Expertise and the Influence of Political Culture on Advice for Policy since Fulton,” Contemporary British History 29, no. 1 (2014).

27 Will Woodward and Rebecca Smithers, "Clarke Dismisses Medieval Historians," The Guardian, May 9, 2003.

28 Evan Dyer, “'Deliverology' Guru Schools Trudeau Government for 2nd Time at Cabinet Retreat," CBC News 2016.

29 Julia Olmos-Peñuela, Paul Benneworth, and Elena Castro-Martínez, "Are Sciences Essential and Humanities Elective? Disentangling Competing Claims for Humanities' Research Public Value," Arts and Humanities in Higher Education 14, no. 1 (2015).

30 Jack Grove, "Social Sciences and Humanities Faculties 'to Close' in Japan after Ministerial Intervention,” Times Higher Education, September 14, 2015. 
the problem of history being both dangerous and pointless in political terms is a task that involves a much broader 'we'. A history with 'public purpose' needs to engage, involve and animate the public - a principle easily invoked but not always given sufficient critical attention. Hodel's paper pointed us to the architecture of archives, and how such buildings communicate ideas about access and entitlement to the records of the past. His argument has a wider importance. The institutions in which we work, the associations in which we gather and through which we conduct our advocacy, the forums in which we communicate, the measures by which esteem and recognition are granted, and so on, are all professional structures. Like Hodel's archive buildings, these structures are not just 'there'. They instantiate the relational qualities of expertise and authority, creating frameworks that govern how and where - on what terms - the uncredentialled enter the expert world.

So where does this leave us? Peter Seixas has highlighted the 'distance' of history teachers from the academic community, which makes them "tend to see historical knowledge as being created by others." So, he goes on, "to the extent that they receive history as inert, opaque information, it is not surprising that they reproduce those presentations when they turn to face the students in the classroom."31 Public and policymaking communities are also distant from academe and often have few opportunities or frameworks for participating in the construction of historical knowledge. Can we expect them to move beyond 'receiving' accounts of the past, to recognise history as a vital, vibrant, intellectually powerful way of knowing about the world without access to more than inert, opaque information'? I would say no, we cannot, and that shifting the terms of our engagement with public-political debate should be a disciplinary imperative for today. The rise of an emboldened right-wing populism in many parts of the Western world is divisive and troubling - on its fringes it is violent and criminal. It is also radically eroding the ground on which 'experts' and scholars of all kinds can stand in order to contribute constructively to public life. And so I come back to where I started, with the notion of professional identity. Who are we now? Can we as gatekeepers or guardians - or even taxi drivers - realise our public purpose, even act with civil courage? I am not sure we can. Something more fundamental seems necessary: being willing to redefine and reground our mandates, to revisit the limits and the entitlements of our authority and to reconfigure our relationships, not just with power but with our publics.

31 Peter Seixas, "The Community of Inquiry as a Basis for Knowledge and Learning: The Case of History,” American Educational Research Journal 30, no. 2. 


\section{Literature cited}

Carr, Edward. What Is History? Basingstoke: Palgrave Macmillan, 2002.

Cannon, John. Teaching History at University. The History Teacher 22, no. 3 (1989): 245-275.

Clark, Christopher. "Power”. In A Concise Companion to History, edited by Ulinka Rublack. Oxford: Oxford University Press, 2011.

Department of Education and Science. National Curriculum History Working Group: Final Report. London: H.M.S.O., 1990.

Eden, Sally. Green, Gold and Grey Geography: Legitimating Academic and Policy Expertise. Transactions of the Institute of British Geographers 30, no. 3 (2005).

Dyer, Evan. 'Deliverology' Guru Schools Trudeau Government for 2nd Time at Cabinet Retreat," CBC News 2016.

Evans, Richard J. Michael Gove's History Wars. Guardian, July 13, 2013.

Grove, Jack. Social Sciences and Humanities Faculties 'to Close' in Japan after Ministerial Intervention. Times Higher Education, September 14, 2015.

Haydn, Terry. History. In Rethinking the School Curriculum: Values, Aims and Purposes, edited by John Nov White.London: RoutledgeFalmer, 2004.

Hvolbeck, Russell H., and Peter N. Stearns. Thinking and Rethinking History. In History Anew: Innovations in the Teaching of History Today, edited by Robert Blackey. Long Beach, Calif.: California State University Press, 1993.

Jordanova, Ludmilla. History in Practice. 2nd ed. London: Hodder Arnold, 2006.

Levesque, Stephane. Thinking Historically: Educating Students for the Twenty-First Century. Toronto: University of Toronto Press, 2008.

Olmos-Peñuela, Julia, Paul Benneworth, and Elena Castro-Martínez, Are Sciences Essential and Humanities Elective? Disentangling Competing Claims for Humanities' Research Public Value. Arts and Humanities in Higher Education 14, no. 1 (2015): 61-78.

Parsons, Wayne. From Muddling through to Muddling up - Evidence Based Policy Making and the Modernisation of British Government. Public Policy and Administration 17, no. 3 (2002): 43-60.

Samuel, Raphael. Theatres of Memory: Past and Present in Contemporary Culture. London: Verso, 2012.

Seixas, Peter. The Community of Inquiry as a Basis for Knowledge and Learning: The Case of History. American Educational Research Journal 30, no. 2 (1993): 305-324.

Shepherd, Jessica. Michael Gove Labels Professors Critical of New Curriculum as "Bad Academia”. The Guardian, March 21, 2013.

Susskind, Richard, and Daniel Susskind. The Future of the Professions: How Technology Will Transform the Work of Human Experts. Oxford: Oxford University Press, 2015.

Thomas, Hugh. History, Capitalism and Freedom. London: Centre for Policy Studies, 1979.

Tomlinson, Sally, and Danny Dorling. Brexit Has Its Roots in the British Empire - So How Do We Explain It to the Young? New Statesman, May 9, 2016.

Wells, Peter. New Labour and Evidence Based Policy Making: 1997-2007. People, Place \& Policy Online 1, no. 1 (May 22, 2007).

Woodward, Will, and Rebecca Smithers. Clarke Dismisses Medieval Historians. The Guardian, May 9, 2003. 
